\title{
Vertical distribution and analysis of micro-, macroelements and heavy metals in the system soil-grapevine-wine in vineyard from North-West Romania
}

Florin-Dumitru Bora ${ }^{1}$, Claudiu-loan Bunea ${ }^{1 *}$, Teodor Rusu ${ }^{2}$ and Nastasia Pop ${ }^{1}$

\begin{abstract}
Background: The determination of micro-, macroelements and heavy metals in the soil-grapevine-wine system is extremely important for the wine industry, the grape and wine quality, and also for consumer health. The quantitative analysis of 10 elements: $\mathrm{Na}, \mathrm{Ca}, \mathrm{Mg}, \mathrm{Fe}, \mathrm{Cu}, \mathrm{Zn}, \mathrm{Pb}, \mathrm{Cd}, \mathrm{Ni}$, Co were made in soil at different depths and also in grapevines (leaves and canes). For grape juice and wine there were analyzed the concentrations of $\mathrm{Cu}, \mathrm{Zn}, \mathrm{Pb}, \mathrm{Ni}$ and $\mathrm{Cd}$ on three cultivars Fetească albă, Fetească regală and Riesling italian, located in Turulung vineyard, NW Romania. All the elements were detected using flame atomic absorbtion spectrometry (FAAS).

Results: Only the Cu concentration $(\bar{x}=479.64 \mathrm{mg} / \mathrm{kg})$ has higher values than the maximum limit admitted (20 mg/kg). The concentrations of micro-, macroelements and heavy metals in aerial parts of grapevine cultivars occur in the following order: $\mathrm{Ca}>\mathrm{Na}>\mathrm{Mg}>\mathrm{Fe}>\mathrm{Cu}>\mathrm{Zn}>\mathrm{Ni}>\mathrm{Pb}>\mathrm{Co}>\mathrm{Cd}$ in canes and leaves. $\mathrm{Cu}, \mathrm{Pb}, \mathrm{Ni}$ and Zn concentration levels decreased in wine compared to grape must, possibly forming insoluble components that can be removed through sedimentation together with yeasts and lees during fermentation. Cd was under the limit of detection. Heavy metals detected in Romanian wines were below the recommended health limits of the International organization of wine and vine (O.I.V.).

Conclusions: In soil, all the elements studied were under the maximum limit admitted, except, elevated concentrations of $\mathrm{Cu}$. These high values obtained could be an effect of different $\mathrm{Cu}$ treatments in vineyards. In canes and leaves, $\mathrm{Cu}, \mathrm{Zn}, \mathrm{Pb}, \mathrm{Cd}$, Ni had higher concentration levels than in grape juice (must) and wine. Conversely, the metal acumulation of wines obtained by micro-vinification process (in the laboratory) are lower than in must.
\end{abstract}

Keywords: Micro-, Macroelements, Heavy metals, Soil-grapevine-wine, FAAS technology, Vitis vinifera L, Grapevine cultivars

\section{Background}

Different wine and grape cultivars have appeared over the centuries of cultivation, according to the skills and tastes of grape growers and wine makers [1]. Vitis vinifera grapes are frequently used for wine production around the world, especially in Europe. All over the world, approximately $80 \%$ of all grapes are used in

\footnotetext{
* Correspondence: claus_bunea@yahoo.com

'Department of Horticulture and Landscaping, Faculty of Horticulture, University of Agricultural Sciences and Veterinary Medicine, 3-5 Mănăştur Street, 400372 Cluj-Napoca, Romania

Full list of author information is available at the end of the article
}

winemaking and $13 \%$ are consumed as table grapes [2]. The quality and quantity, origin, aroma characteristics and health safety of grape and wine consumption are influenced by environmental and anthropogenic factors [3-5]. Between them, environmental factors are region, orography, eco-climate (e.g. temperature, precipitation, wind, etc.), type and composition of soil [4,5]. Of anthropogenic factors responsible for pollution of vineyards is highlighted inputs resulting from the use of fertilizers and metal-based pesticides, chemical sprays, organic manures, industrial emissions, transportation 
and municipal wastes [6-9] and winemaking technology and storage [10].

Industries from Romania like metallurgy, mining activity (related with the flotation and smelters), energy and fuel production, organic and inorganic pesticide and fertilizer industry (also their application) release wastes containing different heavy metals, in soil and other environmental components [11,12].

Generally vineyard soils are very degraded and more ready to contamination. In this context, heavy metal pollution of vineyard soils is a major environmental problem that can affect plant productivity, food quality and human health. Some metals like $\mathrm{Se}, \mathrm{Fe}, \mathrm{Cu}, \mathrm{Zn}$ and $\mathrm{Mg}$ are essential metals since they play an important role in biological systems, while $\mathrm{Al}, \mathrm{Pb}, \mathrm{Ni}$ and $\mathrm{Cd}$ are non-essential metals as they are toxic even in trace amounts [13,14].

Because most pollutants (in the form of solids or gases) can migrate through wind, surface water or groundwater from source of pollution to vineyards, the number of contaminated areas grows larger every year, and heavy metal pollution is a problem in some viticultural regions from Romania [6,11] and other European countries like Croatia [4], France [9], Greece [15] and Bulgaria [16].

Naturally, around 0.9 million ha of soils, are affected by chemical pollution and 0.2 million of them by excessive pollution. Between all the soil pollution contaminants, heavy metals $(\mathrm{Cu}, \mathrm{Pb}, \mathrm{Zn}$ and $\mathrm{Cd})$ or acid precipitation represent agrresive effects on soil and ussually can be found in areas like Baia Mare, Zlatna or Copşa Mică [17]. These regions from Middle and Northwest Romania are well-known contaminated areas with heavy metals $[18,19]$. Particularly in Baia Mare, two metallurgical factories (Romplumb and Cuprom) are the main sources of pollution for the city $[12,20]$ and also for the neighboring agricultural areas.

The aim of this study is to obtain the overview on micro-, macroelements and heavy metals in the northwestern Romanian vineyard soil, aerial parts of vines, grape juice and wine. Our work evaluated 10 elements: $\mathrm{Na}, \mathrm{Ca}$, $\mathrm{Mg}, \mathrm{Fe}, \mathrm{Cu}, \mathrm{Zn}, \mathrm{Pb}, \mathrm{Cd}, \mathrm{Ni}$, and $\mathrm{Co}$ in 3 grapevine cultivars Fetească regală, Fetească albă and Riesling Italian cultivated in the Turulung area, located at $57 \mathrm{~km}$ (NW) from Baia Mare. Detection of minerals and heavy metal concentrations in the system soil-grapevine-wine has been conducted using flame atomic absorption spectrophotometry (FAAS). FAAS is the most common used technique for trace metals (with relatively high concentrations) quantification in soil, vegetal samples and wine. For some elements present in low concentrations, electrothermal atomic absorption spectrometry (ETAAS) or graphite furnace atomic absorption spectrometry (GFAAS) are used $[5,14]$.

The objectives of the study were to: (i) determine micro-, macroelements and heavy metals in soil, canes and vine leaves, grape juice (must) and wines (young wines - after fermentation); (ii) reveal mobility and bioavailability of trace metals in system soil-grapevine-wine; and (iii) compare obtained data with previous studies.

\section{Results and discussion}

Micro-, macroelements and heavy metals in soil

The characteristic type of soil from Turulung area is Preluvosoil (EL) from Luvisols (LUV) class. The soil is characterized by a $\mathrm{pH}$ from 6.0 to 6.12, a content of 1.3$3.5 \%$ humus, $20-35 \mathrm{ppm}$ mobile $\mathrm{P}, 130-220 \mathrm{ppm}$ mobile $\mathrm{K}, 1.0-2.5 \mathrm{~N}$ index, and redox potential between 361$397 \mathrm{mV}$. Texture is clay-loam, granular structure, wellformed, and after 110-140 cm depth of horizon, structure is prismatic. After the depth of $140 \mathrm{~cm}$ allow waterborne debris of calcium carbonate [21].

Regarding the principal macroelements concentrations from Turulung soil genetic type, it can be observed (Table 1) that the highest $\mathrm{Na}$ and $\mathrm{Ca}$ concentration were found in $20-40 \mathrm{~cm}$ horizon $(6737.44 \mathrm{mg} / \mathrm{kg}$ respective $6699.34 \mathrm{mg} / \mathrm{kg}$ ). These values decrease with the soil depth profile so in $60-80 \mathrm{~cm}$ interval the values were $5397.27 \mathrm{mg} / \mathrm{kg}(\mathrm{Na})$ respective $4400.76 \mathrm{mg} / \mathrm{kg}(\mathrm{Ca})$. For $\mathrm{Mg}$ the situation is different: the highest values were found in $60-80 \mathrm{~cm}$ interval $(4696.27 \mathrm{mg} / \mathrm{kg})$ and the lowest in $20-40(3216.84 \mathrm{mg} / \mathrm{kg})$. It is well known that the great mass of vine active roots is situated in 20 $80 \mathrm{~cm}$ soil interval [22], were the medium values for $\mathrm{Na}$, $\mathrm{Ca}$ and $\mathrm{Mg}$ are comparable with the surface $(0-20 \mathrm{~cm})$. Kment et al. [23] showed that the $\mathrm{Ca}$ and $\mathrm{Mg}$ concentration in soil could be influenced by the parent rock causing the high concentration for $\mathrm{Ca}$ and $\mathrm{Mg}$ in the analyzed soil.

Regarding the microelements analyzed, $\mathrm{Cu}$ concentration has higher values than the maximum limit admitted $(20 \mathrm{mg} / \mathrm{kg})$. It is well-known that $\mathrm{Cu}$ is one of the most studied element in wine-growing regions. It is effective against a high number of crop pests and it is utilised as a fungicide, a bactericide and also as a herbicide [24]. Different $\mathrm{Cu}$ formulations are used against grapevine (Vitis vinifera L.) downy mildew and they have a secondary effect on grapevine powdery mildew and on a wide range of other grapevine insect pests and diseases $[24,25]$. The average value of $\mathrm{Cu}$ for the soils analyzed is $479.638 \mathrm{mg} / \mathrm{kg}$, with a minimum of $433.69 \mathrm{mg} / \mathrm{kg}$ and a maximum of $535.58 \mathrm{mg} / \mathrm{kg}$.

These high values could be an effect of treatments with different $\mathrm{Cu}$ products made during the time $[9,26]$, and also as a pollution effect from the two metallurgical factories in Baia-Mare, Romplumb and Cuprom $(57 \mathrm{~km}$ from Turulung area) which are the main sources of pollution for the city [12] and also for the neighboring agricultural areas. 
Table 1 The concentration of micro-, macroelements and heavy metals in soil from Turulung area $(\mathrm{mg} / \mathrm{kg})$

\begin{tabular}{|c|c|c|c|c|c|c|c|c|c|c|}
\hline $\begin{array}{l}\text { Depth } \\
\text { (cm) }\end{array}$ & $\begin{array}{l}\text { MLA* } \\
- \\
\mathrm{Na}\end{array}$ & $\begin{array}{l}\text { MLA } \\
- \\
\mathrm{Ca} \\
\end{array}$ & $\begin{array}{l}\text { MLA } \\
- \\
\text { Mg } \\
\end{array}$ & $\begin{array}{l}\mathrm{MLA} \\
- \\
\mathrm{Fe} \\
\end{array}$ & $\begin{array}{l}\text { MLA } \\
20 \mathrm{mg} / \mathrm{kg} \\
\mathrm{Cu}\end{array}$ & $\begin{array}{l}\text { MLA } \\
100 \mathrm{mg} / \mathrm{kg} \\
\mathrm{Zn}\end{array}$ & $\begin{array}{l}\mathrm{MLA} \\
20 \mathrm{mg} / \mathrm{kg} \\
\mathrm{Pb}\end{array}$ & $\begin{array}{l}\text { MLA } \\
1 \mathrm{mg} / \mathrm{kg} \\
\mathrm{Cd}\end{array}$ & $\begin{array}{l}\text { MLA } \\
20 \mathrm{mg} / \mathrm{kg} \\
\mathrm{Ni}\end{array}$ & $\begin{array}{l}\text { MLA } \\
15 \mathrm{mg} / \mathrm{kg} \\
\text { Co }\end{array}$ \\
\hline $0-20$ & $6497.49 \pm 367.99 a$ & $5133.91 \pm 434.99 b$ & $3628.81 \pm 241.27 b c$ & $2341.40 \pm 169.80 a b$ & $433.69 \pm 40.82 \mathrm{a}$ & $78.25 \pm 4.49 a$ & $16.27 \pm 0.93 \mathrm{a}$ & $0.56 \pm 0.30 \mathrm{a}$ & $19.23 \pm 0.98 a$ & $9.93 \pm 1.68 \mathrm{ab}$ \\
\hline $20-40$ & $6737.44 \pm 245.50 \mathrm{a}$ & $6699.34 \pm 717.90 \mathrm{a}$ & $3216.84 \pm 282.26 \mathrm{C}$ & $2437.93 \pm 269.95 a$ & $471.15 \pm 22.56 \mathrm{a}$ & $54.58 \pm 2.80 \mathrm{~b}$ & $15.45 \pm 1.18 \mathrm{a}$ & $0.30 \pm 0.01 c$ & $17.70 \pm 1.93 \mathrm{a}$ & $11.31 \pm 1.55 \mathrm{a}$ \\
\hline $40-60$ & $6293.69 \pm 278.38 a$ & $4904.12 \pm 220.65 b$ & $3828.06 \pm 139.96 b$ & $2060.90 \pm 73.68 b$ & $535.58 \pm 84.81 \mathrm{a}$ & $74.31 \pm 4.40 \mathrm{a}$ & $13.72 \pm 0.75 b$ & $0.42 \pm 0.04 b$ & $12.80 \pm 2.55 b$ & $10.28 \pm 1.73 a b$ \\
\hline $60-80$ & $5397.27 \pm 606.76$ b & $4400.76 \pm 262.31$ b & $4696.27 \pm 301.73 a$ & $2016.83 \pm 79.00 \mathrm{~b}$ & $478.13 \pm 67.68 \mathrm{a}$ & $70.63 \pm 4.37 a$ & $13.63 \pm 0.09 b$ & $0.51 \pm 0.05 a$ & $15.40 \pm 2.59 \mathrm{ab}$ & $7.49 \pm 0.90 \mathrm{c}$ \\
\hline \multicolumn{11}{|c|}{ Average } \\
\hline & $6231.47 \pm 374.66$ & $5824.53 \pm 408.96$ & $3842.50 \pm 240.59$ & $2214.27 \pm 148.77$ & $479.64 \pm 53.97$ & $69.44 \pm 4.02$ & $14.77 \pm 0.74$ & $0.45 \pm 0.10$ & $16.28 \pm 2.01$ & $9.75 \pm 1.47$ \\
\hline \multicolumn{11}{|c|}{$\bar{x}(20-80)$} \\
\hline & $6142.80 \pm 376.88$ & $5334.74 \pm 400.29$ & $3913.72 \pm 240.32$ & $2172.89 \pm 140.87$ & $494.95 \pm 58.35$ & $66.51 \pm 3.86$ & $14.27 \pm 0.27$ & $0.41 \pm 0.03$ & $15.30 \pm 2.36$ & $9.69 \pm 1.39$ \\
\hline \multicolumn{11}{|c|}{ Minimum values } \\
\hline & $5397.27 \pm 606.76$ & $4400.76 \pm 262.31$ & $3216.84 \pm 282.26$ & $2016.83 \pm 79.00$ & $535.58 \pm 84.81$ & $54.58 \pm 2.80$ & $13.63 \pm 0.09$ & $0.30 \pm 0.01$ & $12.80 \pm 2.55$ & $7.49 \pm 0.90$ \\
\hline \multicolumn{11}{|c|}{ Maximum values } \\
\hline & $6737.44 \pm 245.50$ & $6699.34 \pm 717.90$ & $4696.27 \pm 301.73$ & $2437.93 \pm 269.95$ & $433.69 \pm 40.82$ & $78.25 \pm 4.49$ & $16.27 \pm 0.93$ & $0.56 \pm 0.30$ & $19.23 \pm 0.98$ & $11.31 \pm 1.55$ \\
\hline
\end{tabular}

Average value \pm standard deviation $(n=3)$. Different letters are significantly different for $P \leq 0.05$ between depths. The difference between any two values, followed by at least one common letter, is insignificant. $M L A^{*}=$ maximum limit allowed.

$\bar{x}(20-80)=$ In the conditions of Romania, most roots vines are grown in soil layers from about 20 to $80 \mathrm{~cm}$ [22]. 
In one study, the world average values for $\mathrm{Cu}$ in soil is reported as $30 \mathrm{mg} / \mathrm{kg}$ (from 2 to $250 \mathrm{mg} / \mathrm{kg}$ ) [27] but other studies showed values from 200 to $500 \mathrm{mg} / \mathrm{kg}[9,28]$.

However, concentrations of copper in our study were comparable to those found in other vineyards. For example, studies carried out in vineyards without smelters activities like in Spain, indicate a mean of $35.4 \mathrm{mg} / \mathrm{kg}$ [29,30]; $179-579 \mathrm{mg} / \mathrm{kg}$ in top soil [31], in France 22$398 \mathrm{mg} / \mathrm{kg}$ in top soil $(0-30 \mathrm{~cm})$ [28] and $227 \mathrm{mg} / \mathrm{kg}$ for the deep horizon $(35-40 \mathrm{~cm})$ [9], while in Brazil the vineyard soils presents very high concentrations (up to $3216 \mathrm{mg} / \mathrm{kg} \mathrm{Cu}$ ) [32]. Conversely, in industrially polluted region from Bulgaria, $\mathrm{Cu}$ registred a maximum of $72.3 \mathrm{mg} / \mathrm{kg}$ [33]; $229.15 \mathrm{mg} / \mathrm{kg}$ in old mining area from Banat county [18], and 440-5823 ppm in Baia Mare, Romania, very close to metallurgical smelter factories [12].

$\mathrm{Zn}$ values were between $54.58-78.25 \mathrm{mg} / \mathrm{kg}$, under the maximum limit admitted $(100 \mathrm{mg} / \mathrm{kg})$. Compared with the data from the literature, the values obtained for $\mathrm{Zn}$ in Turulung are slighty higher than the world soil average $(50 \mathrm{mg} / \mathrm{kg})$ [27], but appropriate with the values reported in the Castelon region, Spain $(76.8 \mathrm{mg} / \mathrm{kg})$ [29]. The $\mathrm{Zn}$ content from the Huşi vineyard area (Romania) varied between 43.1 and $103 \mathrm{mg} / \mathrm{kg}$, with an average of $73.9 \mathrm{mg} / \mathrm{kg}$ [6]. Regarding the depths from the Brestnik area, Bulgaria, the $\mathrm{Zn}$ content decrease from the surface $(0-10 \mathrm{~cm})$ to the deep horizon $(30-40 \mathrm{~cm})$, namely from $243 \mathrm{mg} / \mathrm{kg}$ to $187 \mathrm{mg} / \mathrm{kg}$ [33]. The same situation is in our study $(78.25 \mathrm{mg} / \mathrm{kg}$ at $0-20 \mathrm{~cm}$ to $54.58 \mathrm{mg} / \mathrm{kg}$ at $20-40 \mathrm{~cm}$ ) and also in the Champagne region, France (from $318 \mathrm{mg} / \mathrm{kg}$ in the topsoil at $5-10 \mathrm{~cm}$ to $208 \mathrm{mg} / \mathrm{kg}$ in the deep horizon at $35-40 \mathrm{~cm}$ ) [9].

$\mathrm{Pb}, \mathrm{Cd}, \mathrm{Ni}$, Co levels were under the maximum limit admitted. Except for Co, the other heavy metals like $\mathrm{Pb}$, $\mathrm{Cd}$ and $\mathrm{Ni}$ recorded the highest values in the surface $(0-20 \mathrm{~cm})$. In the Turulung vineyard soil, $\mathrm{Pb}$ recorded a total average of $14.77 \mathrm{mg} / \mathrm{kg}$, varying from a minimum value of 13.63 to a maximum value of $16.27 \mathrm{mg} / \mathrm{kg}$. These values are comparable with those obtained in Huși area, Romania, $19.9 \mathrm{mg} / \mathrm{kg}$ [6], Douro basin, Portugal, $28.8 \mathrm{mg} / \mathrm{kg}$ [34], and Castelon region, Spain, $56.1 \mathrm{mg} / \mathrm{kg}$ [29].

In case of $\mathrm{Cd}$, the average content $(0.44 \mathrm{mg} / \mathrm{kg})$; slightly higher than background $(0.40 \mathrm{mg} / \mathrm{kg})$ for $\mathrm{Cd}$ in world soils, presented by [27] and lower compared with the value registred in the Castelon region, Spain $(0.358 \mathrm{mg} / \mathrm{kg})$ [29].

The total average of $\mathrm{Ni}$ for the Turulung area soil is $19.23 \mathrm{mg} / \mathrm{kg}$ lower than the world soil average value for $\mathrm{Ni}(40 \mathrm{mg} / \mathrm{kg})$ reported by [27]. Total content mean in the Castelon area, Spain was $19.9 \mathrm{mg} / \mathrm{kg} \mathrm{Ni}$ [29] and mean value of $28 \mathrm{mg} / \mathrm{kg}$ was recorded in the Douro basin, Portugal [34]. In the vineyard from SW of Romania, the $\mathrm{Ni}$ content ranges between 13.82 and $31.18 \mathrm{mg} / \mathrm{kg}$ for a $0-10 \mathrm{~cm}$ depth [11].
Finally, the Co content from the study area varies between $7.49 \mathrm{mg} / \mathrm{kg}$ and $11.31 \mathrm{mg} / \mathrm{kg}$, with an average of $9.75 \mathrm{mg} / \mathrm{kg}$. According to [27], based on the data from the literature, the values vary within a range, from 2 to $40 \mathrm{mg} / \mathrm{kg}$ Co for world soils, a total content of $7.9 \mathrm{mg} / \mathrm{kg}$ for Spain [29], and a average of $12 \mathrm{mg} / \mathrm{kg}$ for the Douro basin, Portugal [34].

\section{Micro-, macroelements and heavy metals in canes and leaves}

The concentration levels of micro-, macroelements and heavy metals in aerial parts (canes and leaves) of vinegrape cultivars were determinated. Thus, minerals studied represented the following order: $\mathrm{Ca}>\mathrm{Na}>\mathrm{Mg}>\mathrm{Fe}>$ $\mathrm{Cu}>\mathrm{Zn}>\mathrm{Ni}>\mathrm{Pb}>\mathrm{Co}>\mathrm{Cd}$ in canes and $\mathrm{Ca}>\mathrm{Mg}>\mathrm{Na}>$ $\mathrm{Fe}>\mathrm{Cu}>\mathrm{Zn}>\mathrm{Ni}>\mathrm{Pb}>\mathrm{Co}>\mathrm{Cd}$ in leaves (Tables 2 and 3). Between macroelements analyzed, $\mathrm{Ca}$ with $2521.57 \mathrm{mg} / \mathrm{kg}$ in canes, and $3005.27 \mathrm{mg} / \mathrm{kg}$ in leaves recorded the highest concentration. These values were lower than in canes from the Turkey (from $5950 \pm$ $50 \mathrm{mg} / \mathrm{kg}$ to $10210 \pm 120 \mathrm{mg} / \mathrm{kg}$ ) but in case of Fe concentration, our results (average $400.15 \pm 6.72 \mathrm{mg} / \mathrm{kg}$ ) were higher (from $2.6 \mathrm{mg} / \mathrm{kg}$ to $6.8 \mathrm{mg} / \mathrm{kg}$ ) [35]. Regarding heavy metals levels in canes from study area Turulung (Romania) the averages were: $0.13 \pm 0.02 \mathrm{mg} / \mathrm{kg}$ $\mathrm{Cd}, 2.02 \pm 0.19 \mathrm{mg} / \mathrm{kg}-\mathrm{Pb}, 9.87 \pm 0.44 \mathrm{mg} / \mathrm{kg}-\mathrm{Ni}, 13.97 \pm$ $1.30 \mathrm{mg} / \mathrm{kg}-\mathrm{Zn}$ and $55.02 \pm 2.54 \mathrm{mg} / \mathrm{kg}-\mathrm{Cu}$ (Table 2). For $\mathrm{Zn}$ the values were lower than reported by [35] in canes from the Experimental Vineyard of Suleyman Demirel University (Isparta, Turkey).

Between heavy metals in leaves (Table 3) the concentration levels of $\mathrm{Cu}$ (average $49.16 \pm 3.40 \mathrm{mg} / \mathrm{kg}$ ) and $\mathrm{Pb}$ (average $4.25 \pm 0.03 \mathrm{mg} / \mathrm{kg}$ ) were higher than in leaves from the Ucraina $(\mathrm{Cu}$ is $9.91 \pm 0.9 \mathrm{mg} / \mathrm{kg}$ and $\mathrm{Pb}$ is $0.99 \pm$ $0.16 \mathrm{mg} / \mathrm{kg})$ [3], France $(\mathrm{Cu}$ is $6.7 \mathrm{mg} / \mathrm{kg}$ and $\mathrm{Pb}$ is $0.8 \mathrm{mg} / \mathrm{kg}$ ) [9] and other leafy vegetables grown in contaminated mining areas from Romania (from $0.29 \mathrm{mg} / \mathrm{kg}$ to $4.79 \mathrm{mg} / \mathrm{kg}$ for $\mathrm{Cu}$ and $0.03 \mathrm{mg} / \mathrm{kg}$ to $1.79 \mathrm{mg} / \mathrm{kg}$ for $\mathrm{Pb}$ ) [18].

In south-west Romania (Caras Severin County) in which pollution was generated for many decades by extractive and metallurgical industry [11] recorded for $\mathrm{Pb}$ a range of $0.18-6.56 \mathrm{mg} / \mathrm{kg}$, for $\mathrm{Ni} 0.37-2.58 \mathrm{mg} / \mathrm{kg}$, and for $\mathrm{Cd} 0.10-1.10 \mathrm{mg} / \mathrm{kg}$. These values are similar whith our results.

$\mathrm{Zn}$ was found in the average of $25.20 \pm 1.37 \mathrm{mg} / \mathrm{kg}$ (Table 2) less than those from France (average Zn content is $29.3 \mathrm{mg} / \mathrm{kg}$ ) [9] and Ucraina (average $\mathrm{Zn}$ content is $28 \mathrm{mg} / \mathrm{kg}$ ) [3].

\section{Heavy metals in grape juice (must) and wine}

The concentrations of heavy metals in grape must samples decrease in the order $\mathrm{Cu}>\mathrm{Zn}>\mathrm{Pb}>\mathrm{Ni}>\mathrm{Cd}$, for majority of winegrape cultivars studied. The concentration levels of 
Table 2 The concentration of micro-, macroelements and heavy metals in canes from Turulung area (mg/kg)

\begin{tabular}{|c|c|c|c|c|c|c|c|c|c|c|}
\hline & $M L A *$ & MLA & MLA & MLA & MLA & MLA & MLA & MLA & MLA & MLA \\
\hline & - & - & - & - & - & - & - & - & - & - \\
\hline Element Cultivar & $\mathrm{Na}$ & $\mathrm{Ca}$ & $\mathrm{Mg}$ & $\mathrm{Fe}$ & $\mathrm{Cu}$ & Zn & $\mathrm{Pb}$ & $\mathrm{Cd}$ & $\mathrm{Ni}$ & Co \\
\hline Fetească albă & $1147.55 \pm 16.74 b$ & $2593.88 \pm 157.91 \mathrm{a}$ & $817.40 \pm 18.10 \mathrm{c}$ & $382.27 \pm 4.64 \mathrm{C}$ & $39.34 \pm 1.80 \mathrm{~b}$ & $15.04 \pm 1.47 \mathrm{a}$ & $2.28 \pm 0.17 \mathrm{a}$ & $0.16 \pm 0.02 \mathrm{a}$ & $9.81 \pm 0.45 b$ & $1.18 \pm 0.23 b$ \\
\hline Fetească regală & $1259.19 \pm 22.78 \mathrm{a}$ & $2619.36 \pm 163.45 \mathrm{a}$ & $888.47 \pm 10.41 b$ & $400.37 \pm 4.89 b$ & $62.05 \pm 3.14 a$ & $12.09 \pm 1.59 b$ & $1.32 \pm 0.19 b$ & $0.13 \pm 0.03 \mathrm{a}$ & $11.11 \pm 0.66 \mathrm{a}$ & $1.67 \pm 0.20 b$ \\
\hline Riesling italian & $1027.06 \pm 17.81 \mathrm{C}$ & $2350.48 \pm 123.59 \mathrm{a}$ & $958.44 \pm 23.68 \mathrm{a}$ & $417.82 \pm 10.63 a$ & $63.67 \pm 2.67 \mathrm{a}$ & $14.77 \pm 0.83 a b$ & $2.46 \pm 0.22 \mathrm{a}$ & $0.10 \pm 0.02 \mathrm{a}$ & $8.69 \pm 0.23 c$ & $2.53 \pm 0.43 a$ \\
\hline \multicolumn{11}{|l|}{ Average } \\
\hline & $1144.60 \pm 19.11$ & $2521.57 \pm 148.31$ & $888.10 \pm 17.39$ & $400.15 \pm 6.72$ & $55.02 \pm 2.54$ & $13.97 \pm 1.30$ & $2.02 \pm 0.19$ & $0.13 \pm 0.02$ & $9.87 \pm 0.44$ & $1.79 \pm 0.28$ \\
\hline \multicolumn{11}{|l|}{ Minimum values } \\
\hline & $1027.06 \pm 17.81$ & $2350.48 \pm 123.59$ & $817.40 \pm 18.10$ & $382.27 \pm 4.64$ & $39.34 \pm 1.80$ & $12.09 \pm 1.59$ & $1.32 \pm 0.19$ & $0.10 \pm 0.02$ & $8.69 \pm 0.23$ & $1.18 \pm 0.23$ \\
\hline \multicolumn{11}{|l|}{ Maximum values } \\
\hline & $1259.19 \pm 22.78$ & $2619.36 \pm 163.45$ & $958.44 \pm 23.68$ & $417.82 \pm 10.63$ & $63.67 \pm 2.67$ & $15.04 \pm 1.47$ & $2.46 \pm 0.22$ & $0.16 \pm 0.02$ & $11.11 \pm 0.66$ & $2.53 \pm 0.43$ \\
\hline
\end{tabular}

Average value \pm standard deviation $(n=3)$. Different letters are significantly different for $P \leq 0.05$ between varieties. The difference between any two values, followed by at least one common letter, is insignificant. $M L A^{*}=$ maximum limit allowed. 
Table 3 The concentration of micro-, macroelements and heavy metals in leaves from Turulung area $(\mathrm{mg} / \mathrm{kg})$

\begin{tabular}{|c|c|c|c|c|c|c|c|c|c|c|}
\hline & MLA* & MLA & MLA & MLA & MLA & MLA & MLA & MLA & MLA & MLA \\
\hline & - & - & - & - & - & - & - & - & - & - \\
\hline Element Cultivar & $\mathrm{Na}$ & $\mathrm{Ca}$ & Mg & $\mathrm{Fe}$ & $\mathrm{Cu}$ & $\mathrm{Zn}$ & $\mathrm{Pb}$ & $\mathrm{Cd}$ & $\mathrm{Ni}$ & Co \\
\hline Fetească albă & $235.71 \pm 13.51 \mathrm{a}$ & $2820.38 \pm 100.42 b$ & $1453.90 \pm 10.31 \mathrm{a}$ & $122.37 \pm 2.00 \mathrm{~b}$ & $47.23 \pm 2.10 \mathrm{~b}$ & $23.94 \pm 1.55 \mathrm{ab}$ & $4.93 \pm 0.04 \mathrm{a}$ & $0.58 \pm 0.04 c$ & $10.12 \pm 0.59 \mathrm{a}$ & $0.24 \pm 0.02 b$ \\
\hline Fetească regală & $247.50 \pm 11.90 \mathrm{a}$ & $3244.99 \pm 105.10 \mathrm{a}$ & $1381.45 \pm 15.22 b$ & $147.54 \pm 4.12 \mathrm{a}$ & $58.19 \pm 4.47 a$ & $27.05 \pm 1.39 a$ & $3.12 \pm 0.03 b$ & $0.79 \pm 0.02 b$ & $9.23 \pm 0.90 \mathrm{a}$ & $0.33 \pm 0.07 b$ \\
\hline Riesling italian & $188.55 \pm 6.57 \mathrm{~b}$ & $2950.45 \pm 74.95$ b & $1096.26 \pm 7.24 \mathrm{C}$ & $143.29 \pm 6.29 a$ & $42.05 \pm 3.63 b$ & $24.62 \pm 1.17 \mathrm{~b}$ & $4.69 \pm 0.02 \mathrm{a}$ & $0.93 \pm 0.02 \mathrm{a}$ & $9.06 \pm 0.75 a$ & $0.85 \pm 0.11 \mathrm{a}$ \\
\hline \multicolumn{11}{|l|}{ Average } \\
\hline & $223.92 \pm 10.66$ & $3005.27 \pm 93.49$ & $1310.54 \pm 10.92$ & $137.73 \pm 4.14$ & $49.16 \pm 3.40$ & $25.20 \pm 1.37$ & $4.25 \pm 0.03$ & $0.77 \pm 0.03$ & $9.47 \pm 0.75$ & $0.47 \pm 0.07$ \\
\hline \multicolumn{11}{|l|}{ Minimum values } \\
\hline & $188.55 \pm 6.57$ & $2820.38 \pm 100.42$ & $1096.26 \pm 7.24$ & $122.37 \pm 2.00$ & $42.05 \pm 3.63$ & $23.94 \pm 1.55$ & $3.12 \pm 0.03$ & $0.58 \pm 0.04$ & $9.06 \pm 0.75$ & $0.24 \pm 0.02$ \\
\hline \multicolumn{11}{|l|}{ Maximum values } \\
\hline & $247.50 \pm 11.90$ & $3244.99 \pm 105.10$ & $1453.90 \pm 10.31$ & $147.54 \pm 4.12$ & $58.19 \pm 4.47$ & $27.05 \pm 1.39$ & $4.93 \pm 0.04$ & $0.93 \pm 0.02$ & $10.12 \pm 0.59$ & $0.85 \pm 0.11$ \\
\hline
\end{tabular}

Average value \pm standard deviation $(n=3)$. Different letters are significantly different for $P \leq 0.05$ between varieties. The difference between any two values, followed by at least one common letter, is insignificant. $\mathrm{MLA}^{*}=$ maximum limit allowed. 
$\mathrm{Zn}$ in white must ranged from $5.02 \mathrm{mg} / \mathrm{L}$ in Fetească regală to $7.93 \mathrm{mg} / \mathrm{L}$ in Fetească albă, and $\mathrm{Cu}$ was from $8.77 \mathrm{mg} / \mathrm{L} \mathrm{mg}$ in Fetească regală to $10.22 \mathrm{mg} / \mathrm{L}$ in Riesling italian (Figure 1).

The higher concentration levels of $\mathrm{Cu}$ were observed in Riesling italian compared to Fetească albă and Fetească regală, Zn level are higher in Fetească albă, while $\mathrm{Ni}$ and $\mathrm{Pb}$ present higher concentrations in Fetească regală, which can be linked to different accumulation patterns in the cultivars. A previous study by Ko et al. [36] reported the variation of accumulation patterns of trace metals depending on the type of cultivar.

The results represent a higher heavy metals content to the grape juice from Ukraine [3], Brasil [37], Portugal [38] and other vinegrowing area from Romania [39]. It was expected to obtain higher concentrations for heavy metals analyzed because the study area (Turulung) is located close to Baia Mare.

The concentration level of $\mathrm{Cu}$ decreased from $9.32 \mathrm{mg} / \mathrm{L}$ in grape juice to $0.23 \mathrm{mg} / \mathrm{L}$ in the wine from Fetească albă cultivar, from $8.77 \mathrm{mg} / \mathrm{L}$ in grape juice to $0.32 \mathrm{mg} / \mathrm{L}$ in the wine from Fetească regală cultivar and from $10.22 \mathrm{mg} / \mathrm{L}$ in grape juice to $0.15 \mathrm{mg} / \mathrm{L}$ in the wine from Riesling italian cultivar. The same decreasing trend is observed also for the other elements analyzed $(\mathrm{Ni}, \mathrm{Pb}$ and $\mathrm{Zn})$ at all three cultivars tested. Particularly, cv. Fetească regală recorded higher concentration levels for all elements (except $\mathrm{Ni}$ ) and cv. Riesling italian the lower (except $\mathrm{Ni}$ ).

$\mathrm{Cu}, \mathrm{Pb}, \mathrm{Ni}$ and $\mathrm{Zn}$ concentration levels decreased in wine compared to grape must, possibly forming insoluble components that can be removed through

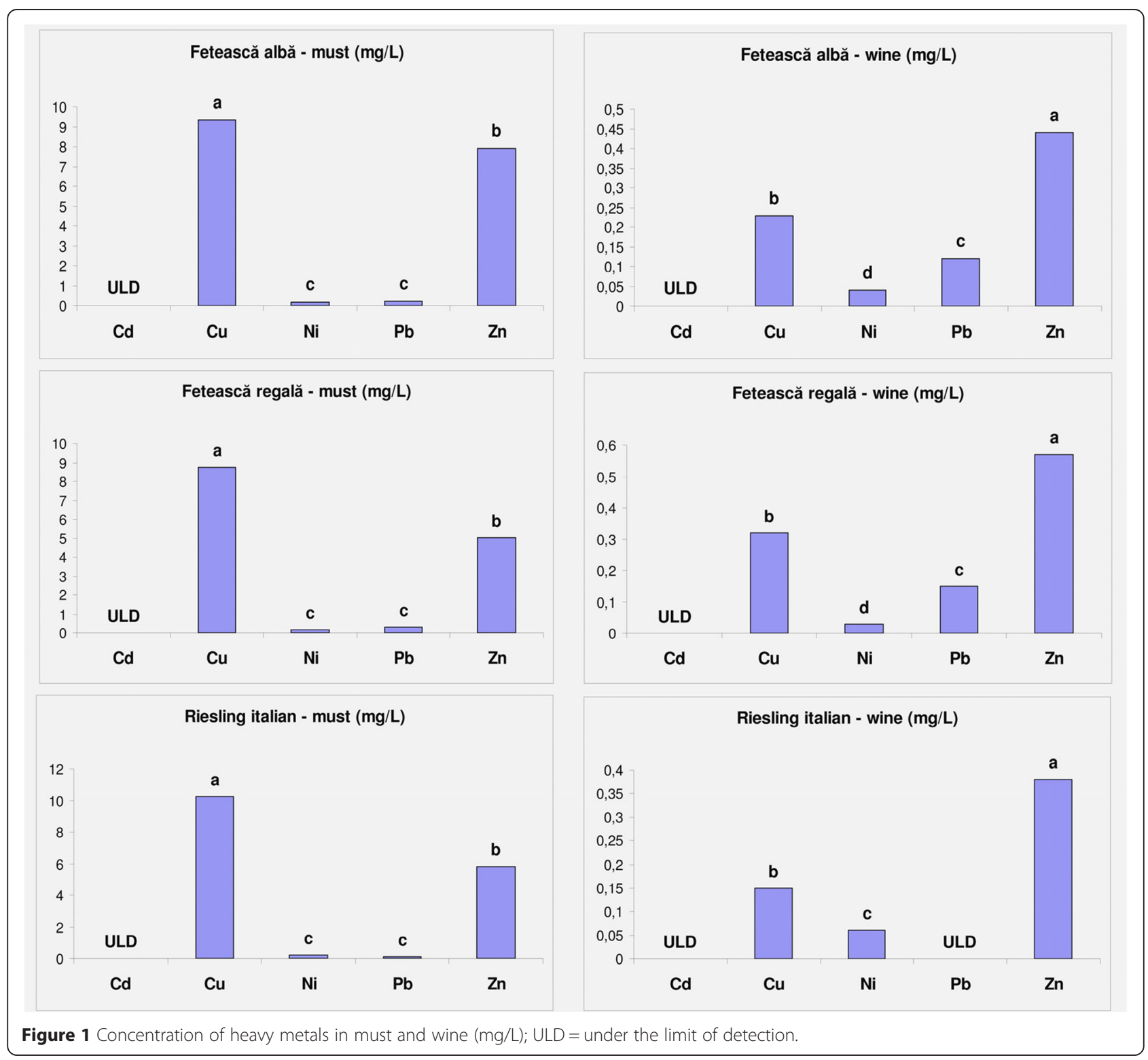


sedimentation together with yeasts and lees during fermentation [40]. Cd was for all cultivars under the limit of detection (in must and wines).

By comparing the values for heavy metals in wines found in literature (Table 4) with the concentration levels of $\mathrm{Cd}, \mathrm{Cu}, \mathrm{Ni}, \mathrm{Pb}$, and $\mathrm{Zn}$ in young white wines obtained in Turulung area (NW Romania), we can see that all three wines were similar with the values found in some European countries. $\mathrm{Cd}, \mathrm{Cu}, \mathrm{Zn}$ and $\mathrm{Pb}$ in Romanian wine were below the recommended health limits of the International organisation of Vine and Wine (OIV) [41].

\section{Traceability of heavy metals in system soil-grapevine-wine}

The mobility ratio (MR) in Vitis vinifera L. was used by Serbula et al. [42] and Vystavna et al. [3] to determine the ratio of heavy metals concentration levels $\left(C_{\text {plant }}\right.$, $\mathrm{mg} / \mathrm{kg}$ ) in plant parts (leaves and grapes) to the concentration level of the acid-soluble metal fraction $\left(\mathrm{C}_{\text {soil-m }}\right.$, $\mathrm{mg} / \mathrm{kg}$ ) in the top-soil $\mathrm{MR}=\mathrm{C}_{\text {plant }} / \mathrm{C}_{\text {soil-m}}$.

In other studies accumulation ratio (AR) was used to determine the ratio of metals concentration in plant parts (leaves and grapes) to its pseudo-total concentration $\left(\mathrm{C}_{\text {soil-t, }}\right.$, $\mathrm{mg} / \mathrm{kg})$ in the top-soil $\left(\mathrm{AR}=\mathrm{C}_{\text {plant }} / \mathrm{C}_{\text {soil- } \mathrm{t}}\right)[3,9]$.

In our study transfer factors (TF) were calculated to reveal traceability and bioavailability of heavy metals $(\mathrm{Cu}, \mathrm{Zn}, \mathrm{Pb}, \mathrm{Cd}, \mathrm{Ni})$, in system soil-grapevine-wine. Thus were calculated: $\mathrm{TF}_{\mathrm{cs}}=\mathrm{C}_{\text {canes }} / \mathrm{C}_{\text {soil }}, \mathrm{TF}_{\mathrm{lc}}=\mathrm{C}_{\text {leaves }} /$ $\mathrm{C}_{\text {canes }}, \mathrm{TF}_{\mathrm{mc}}=\mathrm{C}_{\text {must }} / \mathrm{C}_{\text {canes }}, \mathrm{TF}_{\mathrm{wm}}=\mathrm{C}_{\text {wine }} / \mathrm{C}_{\text {must }}$ as the ratio between heavy metal concentration of: canes-soil; leaves-canes; must-canes respectively wine-must. The results obtained are shown in Table 5.

In the case of transfer factor leaves-canes $\left(\mathrm{TF}_{\mathrm{lc}}\right)$ the highest values were obtained for $\mathrm{Cd}$ and $\mathrm{Pb}$. Conversely the analysis of average contents in heavy metals from canes, leaves, must and wines showed that the highest average contents for $\mathrm{Pb}(2.144 \mathrm{mg} / \mathrm{kg})$ and $\mathrm{Cd}$ $(6.334 \mathrm{mg} / \mathrm{kg})$ were found in leaves.

This highlights the behavior of vine regarding to the aggression of toxic metals like $\mathrm{Pb}$ and $\mathrm{Cd}$. The results show that generally, in response to the accumulation of toxic metals, vine will direct these metals to the leaves in order for their elimination at the end of the growing season.

The heavy metals medium content analysis in must and wine showed lower values compared with leaves and canes. Conversely the wine metal contents (from 0.000 to $0.333 \mathrm{mg} / \mathrm{L}$ ) are lower than in must (from 0.000 to $0.438 \mathrm{mg} / \mathrm{L})$.

From Table 5 it can be observed that the transfer coefficients must-canes $\left(\mathrm{TF}_{\mathrm{mc}}\right)$ and wine-must $\left(\mathrm{TF}_{\mathrm{wm}}\right)$ has subunits values, this fact can be explained through the intent of vine to accumulate metals, especially toxic metals at aerial parts level (leaves, canes). This fact showed that vine has specific mechanisms to block toxic metals accumulation (like $\mathrm{Pb}$ and $\mathrm{Cd}$ ) in aerial parts and in their transfer to the berries (grape juice). This finding is in agreement with other studies $[9,23,43]$.

The physico-chemical and biological processes which take place in must transformation to the wine, generate the reduction of heavy metals. This fact it is showed in metal lower values in wines compared with the values found in must or by the subunits values of the transfer factors.

\section{Conclusions}

The results of our study showed diverse patterns of $\mathrm{Na}$, $\mathrm{Ca}, \mathrm{Mg}, \mathrm{Fe}, \mathrm{Cu}, \mathrm{Zn}, \mathrm{Pb}, \mathrm{Cd}, \mathrm{Ni}$ and $\mathrm{Co}$ accumulation in the soil $(0-80 \mathrm{~cm})$, canes, leaves, grape juice and wines of three winegrape cultivars from the Turulung area, NW Romania. In soil, for all the minerals studied the results were under the maximum limit admitted [44], except for $\mathrm{Cu}$ (average $479.64 \mathrm{mg} / \mathrm{kg}$ while MLA $=20 \mathrm{mg} / \mathrm{kg}$ ). These raised values obtained could be an effect of different copper treatments aplied in vineyard against downy mildew and as an industrial pollution effect. In canes and leaves $\mathrm{Cu}, \mathrm{Zn}, \mathrm{Pb}, \mathrm{Cd}$, Ni had higher concentration levels compared with must and wine. Conversely the wine metal accumulation are lower than in must. The transfer factors calculated showed Vitis vinifera L. specific avoidance strategy for preventing toxicity. Regarding the high amount of $\mathrm{Cu}$ in the soil vineyard, it was

Table 4 Concentration of heavy metals in wines from different European viticulture countries (mg/L)

\begin{tabular}{llllllll}
\hline Origin & Analytical technique & $\mathbf{C u}$ & $\mathbf{Z n}$ & $\mathbf{P b}$ & $\mathbf{N i}$ & $\mathbf{C d}$ & References \\
\hline Spain & ICP-AES & 0.30 & 0.53 & nd & nd & nd & Alvarez et al. [51] \\
Slovenia & FAAS-ETAAS & 0.12 & 0.50 & 0.03 & nd & 0.0003 & Kristl et al. [40] \\
Romania & FAAS & 0.23 & 0.46 & 0.09 & 0.04 & ULD & This study \\
Romania, Moldova & ICP-MS & 0.602 & 0.473 & 0.043 & 0.058 & nd & Geana et al. [52] \\
Ukraine & ICP-AES & 0.48 & 0.45 & 0.03 & 0.06 & nd & Vystavna et al. [3] \\
Greece & FAAS & $0.2-0.6$ & $0.3-3.1$ & $0.018-0.42$ & nd -2.3 & 0.006 & Galani-Nikolakaki et al. [53] \\
OIV & AAS & 1.0 & 5 & 0.15 & - & 0.01 & OIV [41] \\
\hline
\end{tabular}

adapted from Vystavna et al. [3].

nd - was not determined in the referenced study.

ULD - under the limit of detection. 
Table 5 Transfer factors in system soil-grapevine-wine ( $\mathrm{mg} / \mathrm{kg}$ and $\mathbf{m g} / \mathrm{L}) ; \mathrm{STDV}=$ standard deviation; RSD\%= relative standard deviation

\begin{tabular}{|c|c|c|c|c|c|c|}
\hline $\mathrm{TF}_{\mathrm{cs}}=\mathrm{C}_{\text {canes }} / \mathrm{C}_{\text {soil }} \mathrm{C}$ & Canes & & & & & \\
\hline Cultivar & $\mathrm{Cu}$ & $\mathrm{Zn}$ & $\mathrm{Pb}$ & $\mathrm{Cd}$ & $\mathrm{Ni}$ & \\
\hline Fetească albă & 0.079 & 0.226 & 0.160 & 0.400 & 0.641 & \\
\hline Fetească regală & 0.125 & 0.182 & 0.093 & 0.325 & 0.726 & \\
\hline Riesling italian & 0.129 & 0.237 & 0.173 & 0.250 & 0.568 & \\
\hline AVERAGE & 0.111 & 0.215 & 0.142 & 0.325 & 0.645 & $\mathrm{Ni}>\mathrm{Cd}>\mathrm{Zn}>\mathrm{Pb}>\mathrm{Cu}$ \\
\hline STDEV & 0.027 & 0.029 & 0.043 & 0.075 & 0.079 & \\
\hline RSD\% & 24.724 & 13.625 & 30.340 & 23.077 & 12.271 & $\mathrm{~Pb}>\mathrm{Cu}>\mathrm{Cd}>\mathrm{Zn}>\mathrm{Ni}$ \\
\hline $\mathrm{TF}_{\mathrm{IC}}=\mathrm{C}_{\text {leaves }} / \mathrm{C}_{\text {canes }}$ & Leaves & & & & & \\
\hline Cultivar & $\mathrm{Cu}$ & $\mathrm{Zn}$ & $\mathrm{Pb}$ & $\mathrm{Cd}$ & $\mathrm{Ni}$ & \\
\hline$\overline{\text { Fetească albă }}$ & 1.201 & 1.592 & 2.162 & 3.625 & 1.032 & \\
\hline Fetească regală & 0.938 & 2.237 & 2.364 & 6.077 & 0.831 & \\
\hline Riesling italian & 0.660 & 1.561 & 1.907 & 9.300 & 1.043 & \\
\hline AVERAGE & 0.933 & 1.797 & 2.144 & 6.334 & 0.968 & $\mathrm{Cd}>\mathrm{Pb}>\mathrm{Zn}>\mathrm{Ni}>\mathrm{Cu}$ \\
\hline STDEV & 0.270 & 0.382 & 0.229 & 2.846 & 0.119 & \\
\hline RSD\% & 28.951 & 21.254 & 10.685 & 44.936 & 12.314 & $\mathrm{Cd}>\mathrm{Cu}>\mathrm{Zn}>\mathrm{Ni}>\mathrm{Pb}$ \\
\hline $\mathrm{TF}_{\mathrm{mc}}=\mathrm{C}_{\text {must }} \mathrm{C}_{\text {canes }}$ & Must & & & & & \\
\hline Cultivar & $\mathrm{Cu}$ & $\mathrm{Zn}$ & $\mathrm{Pb}$ & $\mathrm{Cd}$ & $\mathrm{Ni}$ & \\
\hline Fetească albă & 0.237 & 0.527 & 0.101 & 0.000 & 0.017 & \\
\hline Fetească regală & 0.141 & 0.415 & 0.242 & 0.000 & 0.018 & \\
\hline Riesling italian & 0.161 & 0.370 & 0.041 & 0.000 & 0.022 & \\
\hline AVERAGE & 0.180 & 0.438 & 0.128 & 0.000 & 0.019 & $\mathrm{Zn}>\mathrm{Cu}>\mathrm{Pb}>\mathrm{Ni}$ \\
\hline STDEV & 0.051 & 0.081 & 0.104 & 0.000 & 0.002 & \\
\hline RSD\% & 28.153 & 18.471 & 80.934 & & 12.837 & $\mathrm{~Pb}>\mathrm{Cu}>\mathrm{Zn}>\mathrm{Ni}$ \\
\hline $\mathrm{TF}_{\mathrm{wm}}=\mathrm{C}_{\text {wine }} / \mathrm{C}_{\text {must }}$ & Wine & & & & & \\
\hline Cultivar & $\mathrm{Cu}$ & $\mathrm{Zn}$ & $\mathrm{Pb}$ & $\mathrm{Cd}$ & $\mathrm{Ni}$ & \\
\hline Fetească albă & 0.025 & 0.055 & 0.522 & 0.000 & 0.235 & \\
\hline Fetească regală & 0.036 & 0.114 & 0.469 & 0.000 & 0.100 & \\
\hline Riesling italian & 0.015 & 0.065 & 0.000 & 0.000 & 0.316 & \\
\hline AVERAGE & 0.025 & 0.078 & 0.330 & 0.000 & 0.217 & $\mathrm{~Pb}>\mathrm{Ni}>\mathrm{Zn}>\mathrm{Cu}$ \\
\hline STDEV & 0.011 & 0.031 & 0.287 & 0.000 & 0.109 & \\
\hline RSD\% & 43.186 & 39.888 & 86.974 & & 50.246 & $\mathrm{~Pb}>\mathrm{Ni}>\mathrm{Cu}>\mathrm{Zn}$ \\
\hline
\end{tabular}

demonstrated that the resulting wine did not present $\mathrm{Cu}$ levels above maximum limit allowed (limit recommended by OIV).

\section{Experimental}

\section{Study area}

The study area Turulung is located at $47^{\circ} 56^{\prime}$ North, $23^{\circ}$ $5^{\prime}$ East, in the Satu Mare county, Romania at $57 \mathrm{~km}$ northwest from Baia Mare city. The European road E 81 passes through Turulung, connecting it to the Republic of Ucraina through the Halmeu Customs (Figure 2). As geological-morphological unit Satu Mare county is situated at the eastern edge of the Pannonian Basin, and is separated from Transylvanian Basin by the volcanic mountains Gutâi-Igniș and Codrului Peak mountains [45]. Turulung vineyard has an altitude of $133 \mathrm{~m}$, annual precipitations $687 \mathrm{~mm}$, and annual average temperature $10.3^{\circ} \mathrm{C}[46]$.

The study area ( 4 ha) is used for the growing of two domestic vine cultivars Fetească albă and Fetească regală, and one international vine cultivar Riesling Italian for the obtain of wines with geographical indication "Sătmar Hills", Romania. All vines were planted since 2007, and the vine plantation was organized with $2.2 \times 0.9 \mathrm{~m}$ distance between rows and plants. Vines were pruned according to the Guyot system and were grown on speliers.

Type of soil is Preluvosoil (EL). This is Luvisols characterized morphologically by: A ocric horizon presence 


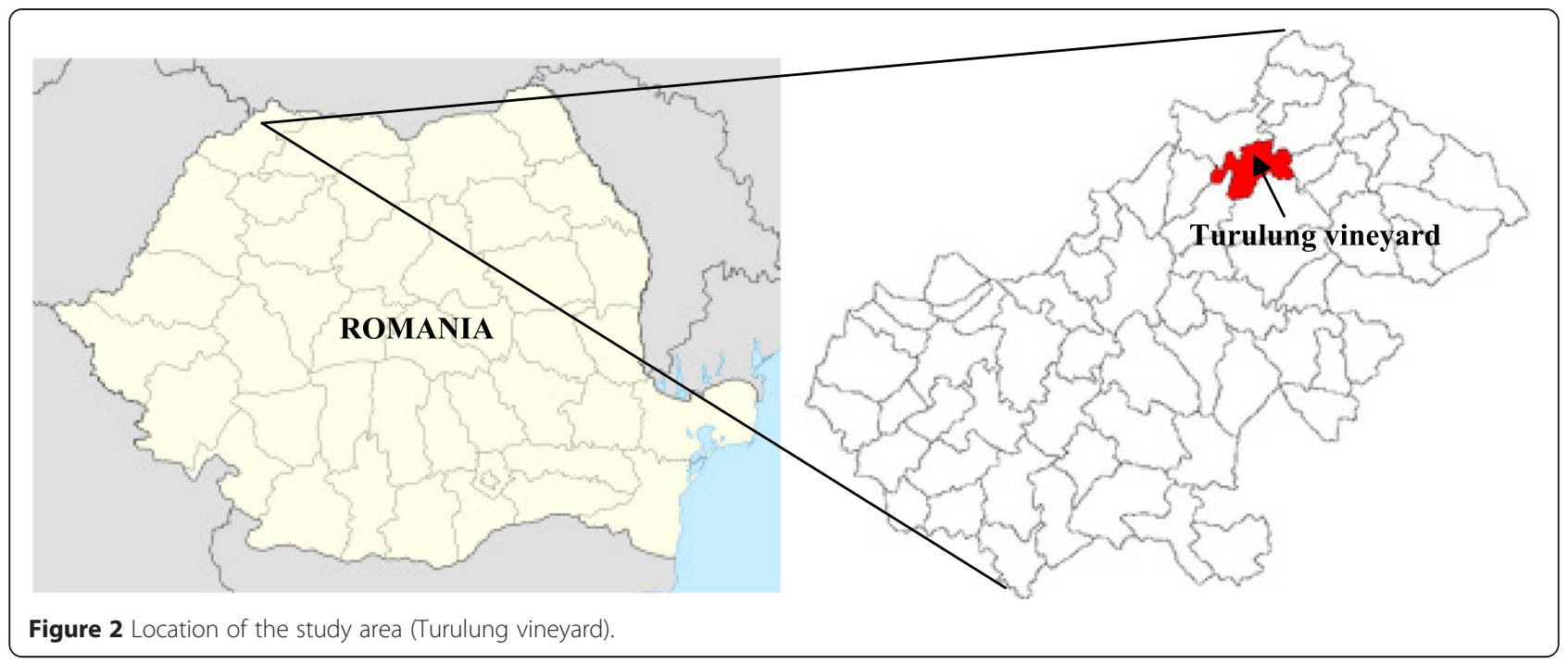

or mollic horizon (Ao, Am) followed by argic intermediate horizon $(\mathrm{Bt})$ with color values exceeding 3.5 at wet material from the top and base saturation level (V\%) over $53 \%$. Preluvosoil typical profile has a slightly shorter than the other soils found in the complex because it meets at the southern slopes, better warm or on a microrelief with good drainage and parent material rich in alkaline elements [21].

\section{Sampling and samples preparation}

The sampling was carried out from August - October 2013 as follows: the soil samplings were done at Turulung in August 2013 on four depths $(0-20 \mathrm{~cm}, 20-40 \mathrm{~cm}, 40-$ $60 \mathrm{~cm}, 60-80 \mathrm{~cm}$ ); sampling of leaves were done in August 2013; sampling of grapes were made in September 2013 and sampling of canes were conducted in October 2013. The study included sampling such as: soil of the vineyard; canes and leaves of Fetească albă, Fetească regală and Riesling Italian cultivars; the first cold pressed grape juice used for the winemaking and young wine after the alcoholic fermentation. All samples were taken in triplicates from the defined experimental plot.

Soil sampling was conducted in accordance with the recommendations of the Order of the Ministry of Agriculture, Food and Forests no. 223, updated and published in Romanian Official Monitor No. 598/13 August 2002 [47]. Soil samples (3 samples/depth) were collected from a depth of $0-20 \mathrm{~cm}, 20-40 \mathrm{~cm}, 40-60 \mathrm{~cm}$, and $60-80 \mathrm{~cm}$ using a handle steel soil sampler. Agrochemical sampling depth of $0-20 \mathrm{~cm}$ is performed after a prior removal of dust, roots, leaves or other residues from the surface. The amount of collected sample is between 0.5 to $1 \mathrm{~kg}$. Each sample is placed in properly labeled plastic bags, closed tightly, ISO 11464/1994. The essential point in the determination of the depth of soil sampling is that the samples should be representative for the depth explored by the roots and also by the fertilizers and amendments incorporation level [48]. Preparation of the samples analysis consisted in removal of foreign matters, milling and sieving of the soil. The soil drying was carried out at a temperature of $105^{\circ} \mathrm{C}$ using an oven model FD 53 Binder. Subsequently samples pulverization and homogenization was performed using an automatic mortar Resh 110 Germany. 50 g of homogenised samples were prelevated for further analysis [49]. For disaggregating soil samples the working protocol ISO 11466/1999 was used. An amount of $0.2-0.5 \mathrm{~g}$ dried and milled material was put into $12 \mathrm{~mL}$ aqua regia $\left(9 \mathrm{~mL} \mathrm{HCl}+3 \mathrm{ml} \mathrm{HNO}_{3}\right)$ and after 15 minutes the mineralization was performed using a microwave Berghof MWS-2, set in 2 steps (at $180^{\circ} \mathrm{C}$ and $100^{\circ} \mathrm{C}$ ). After disaggregation, the samples were filtered through a $0.45 \mathrm{~mm}$ filter and brought to a final volume of $100 \mathrm{~mL}$. For dilution of soil samples was used $50 \mathrm{~mL}$ ultrapure water. Samples filtration and dilution was done according with ISO 11466/1999.

Sampling of leaves and canes was done randomized, from 10-12 representative vines for each cultivar on the same plot. From each choosing vine were picked up 2-4 cane pieces $(25 \mathrm{~cm})$ and 2-4 leaves (from different parts of canopy), that make up the sample composed. Samples of plant material which suffered injuries caused by insects or mechanical damage have been removed. After this, the plant material samples were placed in sealed plastic bags, and immediately transported to the laboratory for analysis. All vegetable samples were washed (2-3 times) with double distilled water to remove soil pollutants. After washing, vegetable samples were oven dried at $80^{\circ} \mathrm{C}$ to constant weight. The dried samples were ground, passed through a $2 \mathrm{~mm}$ sieve, mineralized $8 \mathrm{~h}$ at $550^{\circ} \mathrm{C}$ and stored at ambiental temperature before analysis [18]. The micro-, macroelements and 
Table 6 Instrumental conditions for the determination of each element (FAAS technique)

\begin{tabular}{|c|c|c|c|c|c|c|c|}
\hline Element & $\begin{array}{l}\text { Wavelength } \\
(\mathrm{nm})\end{array}$ & $\begin{array}{l}\text { Slit } \\
(\mathrm{nm})\end{array}$ & $\begin{array}{l}\text { Correlation } \\
\text { coefficient }\end{array}$ & $\begin{array}{l}\text { Flame } \\
\left(2300^{\circ} \mathrm{C}\right)\end{array}$ & $\begin{array}{l}\text { Background } \\
\text { correction }\end{array}$ & $\begin{array}{l}\text { LOD* } \\
(\mathrm{mg} / \mathrm{L})\end{array}$ & $\begin{array}{l}\mathrm{LOQ}^{* *} \\
(\mathrm{mg} / \mathrm{L})\end{array}$ \\
\hline $\mathrm{Ca}$ & 422.7 & 0.7 & 1.000000 & Air-acetylene & - & 0.092 & 0.306 \\
\hline $\mathrm{Mg}$ & 285.2 & 0.7 & 1.000000 & Air-acetylene & Deuterium & 0.190 & 0.633 \\
\hline $\mathrm{Fe}$ & 248.3 & 0.2 & 0.999972 & Air-acetylene & Deuterium & 0.110 & 0.366 \\
\hline $\mathrm{Zn}$ & 213.9 & 0.7 & 0.999999 & Air-acetylene & Deuterium & 0.018 & 0.059 \\
\hline $\mathrm{Cu}$ & 324.8 & 0.7 & 0.999979 & Air-acetylene & Deuterium & 0.017 & 0.056 \\
\hline $\mathrm{Ni}$ & 232.0 & 0.2 & 0.999920 & Air-acetylene & Deuterium & 0.020 & 0.066 \\
\hline Co & 240.7 & 0.2 & 0.999900 & Air-acetylene & Halogen & 0.120 & 0.399 \\
\hline $\mathrm{Pb}$ & 283.3 & 0.2 & 0.999853 & Air-acetylene & Deuterium & 0.051 & 0.166 \\
\hline $\mathrm{Cd}$ & 228.8 & 0.7 & 1.000000 & Air-acetylene & Deuterium & 0.028 & 0.093 \\
\hline $\mathrm{Na}$ & 589.0 & 0.2 & 1.000000 & Air-acetylene & - & 0.012 & 0.039 \\
\hline
\end{tabular}

*Detection limit.

**Quantification limit.

- Not used background correction.

heavy metals contents in vegetable samples were carried out in $\mathrm{HNO}_{3}$ solution resulted by plants ash digestion $[18,20]$. Each sample solution was made up with dilute $\mathrm{HNO}_{3}(2 \mathrm{~mol} / \mathrm{L})$ to a final volume of $100 \mathrm{~mL}$ and analyzed by flame atomic absorbtion spectrometry (FAAS). Filtration and dilution of samples was done respecting ISO 11466/1999 (EU rules).

Grape samples (5 kg/cultivar) were collected for each cultivar from 10-12 vines. The grapes were placed in the lower third, middle and top of each vine and grapes were exposed to sun and shade [50]. In this way can achieve better homogenization of the sample grapes. Fetească regală (3 samples), Fetească albă (3 samples) and Riesling Italian (3 samples) grape juices (must) were cold pressed manually. Before the analysis, each juice sample $(50 \mathrm{~mL})$ was diluted in different proportions using distilled water. Young wines (3 samples/ cultivar) were analysed from the corresponding vineyard in November 2013, and measured without the pretreatment and digestion. The wines were produced in the laboratory conditions (micro-vinification) in the same year (2013) as the grapes sampled.

\section{Chemical analysis}

The soil samples, leaves, canes, musts and wines were analysed by FAAS (Perkin Elmer AAnalyst 800, Shelton, USA). Flame-AAS is the official method of analysis for the determination of trace elements with relatively high concentrations according to EU regulations. The analysis precision was usually very good, being on average above $1 \%$ for all the elements considered at the $\mathrm{mg} / \mathrm{L}$ or $\mathrm{mg} / \mathrm{kg}$ concentration level [5].

All reagents used were of analytical grade (Merck, Germany). Stock standard solutions were prepared weekly or whenever an error is suspected due to these solutions. There were used only standard solutions with commercially distilled water (Merck) at a concentration of $1000 \mathrm{mg} / \mathrm{L}$ for mineral elements which will be determined. High purity water from Barnastead Easypure RoDi model D13321, England apparatus was used to prepare the standard solutions. The intermediate solutions were stored in polyethylene bottles and glassware was cleaned by soaking in $10 \% \mathrm{v} / \mathrm{v} \mathrm{HNO}_{3}$ for 24 hours and rinsing at least three times with ultrapure water. For quality control purpose, blanks and triplicates samples $(\mathrm{n}=3)$ were analyzed during the procedure. The variation coefficients were under $10 \%$ and detection limits $(\mathrm{mg} / \mathrm{L})$ were determined by the calibration curve method. LOD (Limit of detection) and LOQ (Limit of quantification) limits were calculated according to the next mathematical formulas: $\mathrm{LOD}=3 \mathrm{SD} / \mathrm{s}$ and $\mathrm{LOQ}=$ $10 \mathrm{SD} / \mathrm{s} \quad(\mathrm{SD}=$ the estimation of the standard deviation of the regression line, and $\mathrm{s}=$ slope of the calibration curve). The results obtained are shown in Table 6 .

\section{Statistical analysis}

The data were expressed as mean \pm standard deviation (SD) of three replications for each sample analyzed. In order to determine the significance differences among values, analysis of variance (ANOVA) and Duncan multiple range tests (MRT) were performed (PoliFact 2010 ANOVA and Duncan's Test PC Program). Significance of difference was defined at the $5 \%$ level $(\mathrm{p}<0.05)$.

\section{Abbreviations}

FAAS: Flame atomic absorption spectrophotometry; O.I.V: International organization of wine and vine; EL: Preluvosoil; LUV: Luvisols; MR: Mobility ratio; C: Concentration; TF: Transfer factor; MLA: Maximum limit allowed; NW: North-West; ISO: International Organization for Standardization; EU: European Union; MV: Millivolts.

\section{Competing interests}

The authors declare that they have no competing interests. 


\section{Authors' contributions}

$\mathrm{FDB}, \mathrm{CIB}, \mathrm{TR}$, and NP, have contributed mainly to the collection of data, study design, sampling of soil, aerial parts of vine, grape juice and wines, interpretation of results and preparation of paper. All authors read and approved the final manuscript.

\section{Acknowledgements}

This paper was published under the frame of European Social Fund, Human Resources Development Operational Programme 2007-2013, project no. POSDRU/159/1.5/S/132765 and under the frame of the Partnership in priority domains - PN II, developed with the support of MEN-UEFISCDI, project no. PN-II-PT-PCCA-2013-4-0015: Expert System for Risk Monitoring in Agriculture and Adaptation of Conservative Agricultural Technologies to Climate Change.

\begin{abstract}
Author details
${ }^{1}$ Department of Horticulture and Landscaping, Faculty of Horticulture, University of Agricultural Sciences and Veterinary Medicine, 3-5 Mănăştur Street, 400372 Cluj-Napoca, Romania. ${ }^{2}$ Department of Technical and Soil Sciences, Faculty of Agriculture, University of Agricultural Sciences and Veterinary Medicine, 3-5 Mănăştur Street, 400372 Cluj-Napoca, Romania.
\end{abstract}

Received: 6 October 2014 Accepted: 25 March 2015

Published online: 12 April 2015

\section{References}

1. German JB, Walzem RL. The health benefits of wine. Annu Rev Nutr. 2000;20:561-93

2. Yang J, Martinson TE, Liu RH. Phytochemical profiles and antioxidant activities of wine grapes. Food Chem. 2009;116:332-9.

3. Vystavna Y, Rushenko L, Diadin D, Klymenko O, Klymenko M. Trace metals in wine and vineyard environment in southern Ukraine. Food Chem. 2014;146:339-44.

4. Fiket Z, Mikac N, Kniewald G. Arsenic and other trace elements in wines of eastern Croatia. Food Chem. 2011;126:941-7.

5. Kostic D, Mitic S, Miletic G, Despotovic S, Zarubica A. The concentrations of $\mathrm{Fe}, \mathrm{Cu}$ and $\mathrm{Zn}$ in selected wines from South-East Serbia. J Serb Chem Soc. 2010;75(12):1701-9.

6. Huzum R, lancu OG, Buzgar N. Geochemical distribution of selected trace elements in vineyard soils from the Huşi area, Romania. Carpath J Earth Environ Sci. 2012;7(3):61-70.

7. Hooda PS. Trace elements in soils. Chichester, UK: John Willey and Sons Ltd; 2010.

8. Bagdatlioglu N, Nergiz C, Ergonul PG. Heavy metal levels in leafy vegetables and some selected fruits. J Consum Protect Food Saf. 2010;5:421-8.

9. Chopin EIB, Marin B, Mkoungafoko R, Rigaux A, Hopgood MJ, Delannoy E, et al. Factors affecting the distribution and mobility of trace elements $(\mathrm{Cu}, \mathrm{Pb}, \mathrm{Zn})$ in a perennial grapevine (Vitis vinifera L.) in the Champagne region of France. Environ Pollut. 2008;156:1092-8.

10. Tariba B. Metals in wine-impact on wine quality and health outcomes. Biol Trace Elem Res. 2011;144:143-56.

11. Albulescu M, Turuga L, Masu S, Uruioc S, Kiraly LS. Study regarding the heavy metal content (lead, chromium, cadmium) in soil and Vitis Vinifera in vineyards from the Caraş-Severin County. Ann West Univ Timişoara Ser Chem. 2009;18(3):45-52.

12. Damian F, Damian G, Lăcătușu R, Macovei G, lepure G, Năprădean I, et al. Soil from the Baia Mare zone and the heavy metals pollution. Carpath J Earth Environ Sci. 2008;3(1):85-98.

13. Gogoașă I, Maruțoiu C, Gergen I, Rada M, Tigae C. The use of vegetables as indicators in determining the environment pollution. Rev Chim. 2005:56:1275-6.

14. Tuzen M, Soylak M. Evaluation of trace element contents in canned foods marketed from Turkey. Food Chem. 2007;102:1089-95.

15. Vavoulidou E, Avramides EJ, Papadopoulos P, Dimitriou A. Trace metals in different crop/cultivation systems in Greece. Water Air Soil Pollut Focus. 2004:4:631-40.

16. Nakov BK, Nakova MB, Rehab MAA. Long-term assessment of pollution problems in grape cenosys. J Environ Protect Ecol. 2002:3(4):890-5.

17. Bora FD, Pop TI, Mihaly L, Bunea Cl, Pop N. Research on the chemical composition of soil with pollutant effect in some vineyards from Northwestern Transylvania. Bull UASVM Horticult. 2013;70(1):53-9.
18. Hărmănescu M, Alda LM, Bordean DM, Gogoașă I, Gergen I. Heavy metals health risk assessment for population via consumption of vegetables grown in old mining area; a case study: Banat County, Romania. Chem Cent J. 201 1;5:64.

19. Damian G, Damian F, Năsui $D$, Pop C, Pricop C. The soils quality from the southern-eastern part of Baia Mare zone affected by metallurgical industry. Carpath J Earth Environ Sci. 2010:5(1):139-47.

20. Lăcătușu R, Lăcătușu AR. Vegetable and fruits quality within heavy metals polluted areas in Romania. Carpath J Earth Environ Sci. 2008;3(2):115-29.

21. Blaga G, Filipov F, Udrescu S, Rusu I, Dumitru V. Pedologie. Cluj-Napoca: Academic Pres; 2005.

22. Pop N. Curs de viticultură generală. Cluj-Napoca: Editura Eikon; 2010.

23. Kment $P$, Mihaljevič $M$, Ettler $V$, Šebek $O$, Strnad L, Rohlová L. Differentiation of Czech wines using multielement composition - A comparison with vineyard soil. Food Chem. 2005;91:157-65.

24. Provenzano MR, El Bilali H, Simeone V, Baser N, Mondelli D, Cesari G. Coppe contents in grapes and wines from a Mediterranean organic vineyard. Food Chem. 2010;122:1338-43.

25. Boubals D. Copper in the control of grapes in France. Vignevini. 2001;28(5):45-7.

26. Komárek M, Cadková E, Chrastný V, Bordas F, Bollinger JC. Contamination of vineyard soils with fungicides: a review of environmental and toxicological aspects. Environ Int. 2010;36:138-51.

27. Adriano DC. Trace metals in terrestrial environments: biogeochemistry, bioavailability, and risks of metals. 2nd ed. New York: Springer-Verlag; 2001.

28. Chaignon V, Sanchez-Neira I, Herrmann P, Jaillard B, Hinsinger P. Copper bioavailability and extractability as related to chemical properties of contaminated soils from a vine-growing area. Environ Pollut. 2003;123:229-38.

29. Peris M, Micò ox- C, Recatalá L, Sánchez R, Sánchez J. Heavy metal contents in horticultural crops of a representative area of the European Mediterranean region. Sci Total Environ. 2007:378:42-8

30. Ramos MC. Metals in vineyard soils of the Penedes area (NE Spain) after compost application. J Environ Manage. 2006;78:209-15.

31. Arias M, Lopez E, Soto B. Copper distribution and fractionation in aggregate fractions from vineyard soils: comparison with zinc. Agrochimica. 2005;49:60-9.

32. Mîrlean N, Roisenberg A, Chies JO. Metal contamination of vineyard soils in the wet subtropics (southern Brazil). Environ Pollut. 2007;149:10-7.

33. Angelova VR, Ivanov AS, Braikov DM. Heavy metals ( $\mathrm{Pb}, \mathrm{Cu}, \mathrm{Zn}$ and $\mathrm{Cd}$ ) in the system soil-grapevine-grape. J Sci Food Agri. 1999;79:713-21.

34. Reis AP, Menezes de Almeida L, Ferreira da Silva E, Sousa AJ, Patinha C, Fonseca EC. Assessing the geochemical inherent quality of natural soils in the Douro river basin for grapevine cultivation using data analysis and geostatistics. Geoderma. 2007;141:370-83.

35. Çetin ES, Altinöz D, Tarçan E, Baydar NG. Chemical composition of grape canes. Ind Crop Prod. 2011;34:994-8.

36. Ko B-G, Vogeler I, Bolan NS, Clothier B, Green S, Kennedy J. Mobility of copper, chromium and arsenic from treated timber into grapevines. Sci Total Environ. 2007;388:35-42.

37. Bragança CV, Melnikov P, Zanoni LZ. Trace elements in fruit juices. Biol Trace Elem Res. 2012;146:256-61.

38. Pessanha S, Carvalho ML, Becker M, von Bohlen A. Quantitative determination on heavy metals in different stages of wine production by total reflection X-ray fluorescence and energy dispersive X-ray fluorescence: comparison on two vineyards. Spectrochimica Acta Part B. 2010;65:504-7.

39. Dehelean A, Măgdaș DA, Cristea G. The carbon isotopes ratio and trace metals content determinations in some Transylvanian fruit juices. AlP Conf Proceed. 2012;1425:171.

40. Kristl J, Veber M, Slekovec M. The contents of $\mathrm{Cu}, \mathrm{Mn}, \mathrm{Zn}, \mathrm{Cd}, \mathrm{Cr}$ and $\mathrm{Pb}$ at different stages of the winemaking process. Acta Chim Slov. 2003;50:123-36.

41. OIV. International organization of wine and vine. International oenological codex. 2013; Available on the official: http://www.oiv.int/oiv/info/ enplubicationoiv\#world, Accessed at 27.06.2014

42. Serbula SM, Miljkovic DD, Kovacevic RM, llic AA. Assessment of airborne heavy metal pollution using plant parts and topsoil. Ecotox Environ Safe. 2012;76:209-14.

43. Kabata-Pendias A, Pendias H. Trace elements in soils and plants. Boca Raton, FL: CRC Press; 2001.

44. Order of the Ministry of Waters, Forests and Environmental Protection No. 756/3 November 1997, approving the regulation on the assessment of environmental pollution, Bucharest, Romania; 1997

45. Szentesi A: Contributions to the study of relevant agrochemical indices of soil variability in northwest country. PhD Thesis. University of Agricultural Sciences and Veterinary Medicine, Cluj-Napoca, Romania; 2002 
46. Weather station, within the Research Station and Agricultural Development. Livada, Satu-Mare County, Romania; 2014

47. Order of the Ministry of Agriculture, Food and Forests. No. 223, updated and published in Romanian Official Monitor No. 598/13 August, Bucharest, Romania; 2002.

48. Rusu M, Toader C, Mărghitaș M, Mihai M. Cartarea Agrochimică - Studiul Agrochimic al Solurilor. Cluj-Napoca: Academic Pres; 2010.

49. Davidescu D, Davidescu V, Radu L. Macroelemente în agricultură. Editura Academiei Republicii Socialiste Romania; 1988.

50. Lung ML: Researches regarding the content in substances with antioxidant effect, at some vine varieties from different culture areas of Romania. PhD Thesis. University of Agricultural Sciences and Veterinary Medicine, Department of Horticulture and Landscaping; Cluj-Napoca, Romania; 2012

51. Alvarez M, Moreno IM, Jos A, Camean AM, Gonzalez AG. Differentiation of two 'Andalusian DO fin' wines according to their metal content ICP-OES by using supervised pattern recogniation methods. Microchm J. 2007;87:72-6.

52. Geana I, lordache A, lonete R, Marinescu A, Ranca A, Culea M. Geographical origin identification of Romanian wines by ICP-MS elemental analysis. Food Chem. 2013;138:1125-34.

53. Galani-Nikolakaki S, Kallithrakas-Kontos N, Katsanos AA. Trace element analysis of Cretan wines and wineproducts. Sci Total Environ. 2002;285:155-63.

\section{Publish with ChemistryCentral and every scientist can read your work free of charge \\ "Open access provides opportunities to our colleagues in other parts of the globe, by allowing anyone to view the content free of charge." \\ W. Jeffery Hurst, The Hershey Company. \\ - available free of charge to the entire scientific community \\ - peer reviewed and published immediately upon acceptance \\ - cited in PubMed and archived on PubMed Central \\ - yours - you keep the copyright \\ Submit your manuscript here: \\ http://www.chemistrycentral.com/manuscript/<smiles>c1ccccc1</smiles> Chemistry Central}

